\title{
Chinese management practices in Kenya: Toward a post-colonial critique
}

\section{International Journal of Human Resource Management}

\author{
Ken Kamoche \\ Nottingham University Business School, \\ Jubilee Campus, \\ Nottingham NG8 1BB, UK. \\ Email: Ken.Kamoche@nottingham.ac.uk
}

\author{
Lisa Qixun Siebers \\ Nottingham Business School, \\ Nottingham Trent University \\ Burton Street, \\ Nottingham NG1 4BU, UK. \\ Email: Qixun.Siebers@ntu.ac.uk
}

\begin{abstract}
While transforming the investment, trading and infrastructural landscape in Africa, Chinese firms are also generating much-publicised controversy about their real motives. Many of the large Chinese firms operating in Africa focus mostly but not exclusively on engineering, infrastructural projects and mining. This Africa-China engagement has only recently begun to receive critical attention in the area of management and organisation studies. With reference to Kenya, we found that this phenomenon is characterised by four key themes: the unique yet diverse motivations of investors, the challenge of reconciling cross-cultural differences, the impact of low-cost strategies, and the boundary-spanning role of managers. This paper also considers the extent to which post-colonial theory might serve as an analytical lens for examining the perceptions and attitudes of Chinese managers as well as the experiences of the Africans who work for them.
\end{abstract}

Key words: Africa, Kenya, China, post-colonial theory, management practices, FDI, cultural differences 


\section{Introduction}

In recent years, China has emerged as Africa's most important trading partner. While statistics differ depending on what sources one reads, the consensus is that in the last ten to fifteen years, Chinese investments into Africa have grown at an astronomical rate. As Gu (2009) points out, it is not the stock of Chinese foreign direct investment (FDI) into Africa that is remarkable but the speed of growth. From the mid-1990s, China-Africa trade doubled every three years, and is expected to grow by $70 \%$ from 2009 to $\$ 300$ billion by 2015 (McMahon, 2011). This followed a shift in policy away from Maoist propaganda to Deng Xiaoping 'socialist modernisation' which demanded trade and investment for economic gains (Taylor, 1998). In 2002, trade value between China and Kenya was US\$186.37 million (Chinese Foreign Ministry, 2006). By 2011, when China became Kenya's second biggest trading partner, trade had risen from US $\$ 18.25$ billion in 2010 to US $\$ 24.28$ billion, and from January to July 2013, the figure was US\$17.3 billion, and continues to grow (State Council Information Office, 2013). The Africa-China phenomenon has attracted the attention of economists and international relations scholars, but is only now beginning to attract the attention of organisation theory and management researchers.

Academic attention and media interest have both tended to focus on the controversial nature of Chinese investments, with China often being viewed as a new colonising power with an insatiable appetite for Africa's resources. The leading recipients of Chinese FDI are resource-rich countries such as South Africa, Nigeria, Zambia, Algeria, Sudan, and the Democratic Republic of Congo (Cheng and Liang, 2011). Furthermore, Africa has previously played a key role in supporting China's quest for soft power (Snow, 1988). Thus, observers contend that China's involvement in Africa is politically motivated (Gill and Reilly, 2007), and lopsided, favouring the much more politically and economically powerful China (e.g. Foster et al., 2008; Kamoche, 2011). The need for caution is supported by recent research which demonstrates that Chinese competition is a credible threat to emerging market low-wage exporters of labour-intensive consumer goods (Eichengreen and Tong, 2006), which has implications for Africa.

With the declining monopoly of the West over Africa's economy, other emerging markets like China will play a decisive part in shaping the future of the continent (Kragelund, 2009). Indeed, the increase in Chinese outward FDI in the past two decades amounts to a challenge of the West's hegemony in Africa (Jackson, 2012). Chinese firms operating in Africa appear to be guided by the principle of 'disruptive innovation' by investing in a geographical region that is relatively unattractive to western firms (see Hart and Christensen, 2002). African countries 
have been urged to learn from their experience with the West and to position themselves as equal partners while dealing with emergent economic players such as India and China (Broadman, 2007). Some observers have noted the prevalence of questionable employment practices and failure to protect workers' rights and safeguard jobs (e.g. Opondo, 2009). Others have characterised China's interest in Africa as the new scramble for Africa, with Africa becoming the new arena for a struggle for resources and markets, thus raising serious doubts about the real benefits for Africa (Southall and Melber, 2009; Taylor, 2006). We seek to enhance the understanding of the nature and dynamics of Chinese investments in Africa, to characterise the motives of a diversity of investors, analyse their human resource strategies, and to scrutinise the experiences of both the Chinese employers and African personnel (both managers and employees).

Much of the current work on Chinese investments in Africa has focused on large Chinese State-Owned-Enterprises (SOEs) which enjoy extensive State-funding and other forms of support, and tend to be associated with large infrastructural works and mining (e.g. Fung and Garcia-Herrero, 2012). We believe these firms constitute an important proportion of the entire China-in-Africa landscape, yet they only tell part of the story. Therefore, we consider a wider range of investments, including privately-owned firms in the telecommunication, construction and manufacturing sectors, a good number of which are large conglomerates, and small proprietorships such as catering and service firms. Noting that African voices are still 'weak' in the context of imposed Western management knowledge, Jackson's (2012: 182) critique poses the question: 'Is China's engagement with African countries likely to make a difference?' In response to this query, we begin by acknowledging that the postcolonial critique has important implications for the emergent Africa-China engagement on a number of levels, which in turn constitute our three key research questions:

First, we ask whether it is plausible to consider China as a homogenous entity with a unified strategy for Africa, with specific reference to Kenya. This assumption, which has engendered the view that 'China' is preoccupied with securing resources, has prevented a more nuanced debate about the nature and scope of these investments. In particular there is little understanding about the cross-cultural, human resource, employment and expatriation issues that pertain to the Afro-China engagement. Second, given the controversy surrounding China's motives in investing in Africa, this research ponders the extent to which the involvement of Chinese firms in Kenya can be described as exhibiting neo-colonial characteristics, thus inviting a post-colonial analytical approach. In particular we ask: in the context of China's historical relationship with Africa, how relevant is the post-colonial critique in shedding light 
on the emergent relationship? Third, we consider whether the Chinese involvement in Kenya continues the apparent Western tendency to denigrate African local/indigenous knowledge and the concomitant pursuit of ethnocentric practices. Specifically, we ask: to what extent are Chinese organisations drawing from local knowledge in navigating the local investment landscape? To do so, we examine the experiences and attitudes of Chinese managers/investors, Kenyan managers/employees and policy-makers, as well as the management practices of Chinese firms, an empirical approach that has not been pursued sufficiently in contemporary Africa-China research. We recognise that there are multiple voices and narratives within this space, some dominant, others passive.

To achieve the above objectives, we conducted in-depth interviews in both Chinese SOEs and private companies operating in Kenya as an initial step toward a more extensive analysis of Africa-China business relations. Our findings help to shed light both on the challenges Chinese firms are facing and the mutual expectations of the African work force and Chinese employers and how these are negotiated, as well as the opportunities this engagement offers to further theory development and to the formulation of a more sustainable socioeconomic engagement. In the sections that follow, we characterise African management research and locate the emergent Africa-China dialogue in context, re-examine the thrust of post-colonial theory, discuss our research findings and offer some directions for further research.

\section{Management research in Africa}

Following prior concerns about the dearth of research and about the appropriateness of Western management practices (e.g. Blunt and Jones, 1992; Kamoche, 2002), there has been a growing body of research on the management of people and organisations in Africa. An exhaustive review of the scope of this corpus of knowledge would require a full paper. Thus, this section aims to provide a flavour of the research context within which we are locating the Africa-China question. Researchers querying the scope to develop contextually valid management practices have begun to look at traditional cultural values and African philosophy, such as Ubuntu, the basic humaneness, spirit of community, and oneness that defines African social relations (Mangaliso, 2001). The emergent corpus of knowledge includes some notable books, such as Kamoche, Debrah, Horwitz, and Muuka (2004a) which offers detailed analyses of the theory and practice of human resources at the national level; Newenham-Kahindi, Kamoche, Chizema and Mellahi (2013), which characterises some of the latest research on the continent; and Jackson (2004), which focuses on the management challenge in a culturally diverse continent. 
A number of special issues on Africa have appeared in the International Journal of Human Resource Management (Kamoche et al., 2012), the Journal of World Business (Kamoche, 2011), and the Journal of Occupational and Organizational Psychology (Walumbwa et al., 2011).

The scope of the emergent recent literature is broad and comprehensive, as typified in the following examples. Amankwah-Amoah and Debrah (2011) analysed the dynamics of employees' inter-firm mobility in the airline industry in Africa. Horwitz (2012) considered the emergent HR practices of Southern African firms in the context of a significant presence of Asian MNCs. Jackson et al. (2008) examined the importance of multiple cultural influences in small and medium enterprises (SMEs) in Kenya. Kamoche and Newenham-Kahindi (2012) examined the knowledge appropriation approaches of two multinational firms in Tanzania. Idiagbon-Oke and Oke (2011) investigated the change implications and effectiveness of implementing flexible work practices in local firms in Nigeria. Okpara and Kabongo (2011) examined the impact of cross-cultural training on expatriate adjustment in an African context. Lituchy et al (2013) considered leadership in Uganda and three non-African countries. Wood et al (2011) examined the relationship between HRM in Mozambique and business systems theory. Gomez et al. (2012) discussed human resource practices in the mergers and acquisition process in the Nigerian banking sector. Much of this work focuses on characterising the emergent practices in context, advancing theory and demonstrating how mainstream theory might be enriched by an analysis of the African experience.

Specifically relating to Chinese firms, common themes include trends in investments and trade, the political-economic debates about the benefits of Chinese FDI, debunking 'myths' of Chinese dominance, the role of Chinese soft power, how Africans view the Africa-China phenomenon, and so forth (e.g. Fijalkowski, 2011; He, 2013; Hanusch, 2012; Jenkins and Edwards, 2006). Some authors suggest that Chinese engagement is driven by resourcedependence on energy and mineral security (Kurlantzick, 2006; Gill et al., 2007) while playing on Africa's 'historic suspicions' of western intentions (Taylor, 2006). Yet, others posit the counter-argument that Chinese authorities speak of engaging on the basis of cooperation and friendship (Thiam and Mulira, 1999; Shaw et al., 2007; Jackson 2012). Brautigam and Tang (2011) have observed that the almost exclusive concern with natural resources has led some to view this engagement as neo-colonial, and benefiting 'African elites' (Kopinski et al., 2011). Others claim that China's current motivation for involvement in Africa has not changed over the decades, and that Chinese firms have no automatic preference for Chinese labour and do so where there are genuine shortages for example in aid projects (e.g. Davies et al., 2008). With 
specific reference to Kenya, Gadzala (2009) found that the benefits of Chinese investments have been exaggerated, in particular by policy and government leaders, and that while Chinese firms have led to some modest job creation and infrastructural improvements, they have negatively impacted Kenya's informal sector. In a continent-wide survey, Hanusch (2012) found that while China is not perceived very differently from other major (Western) powers, Chinese imports are perceived as damaging local economies. Moving closer to the organisational context, Opondo (2009) found extensive evidence of employment law violations including sexual abuse in Chinese textile firms in Kenya, which underscores the need for social responsibility (Cheng and Liang, 2011). Akorsu and Cooke (2011) investigated Chinese and Indian firms investing in Ghana in relation to the national labour laws and international labour standards. Very little of this emergent literature has offered the voices of Chinese investors and the Africans who work for them. We believe there is a need to go beyond the macro-economic, trade and political-economic debates and engage more closely with the Chinese investors and African employees within the context of work and the employment relationship. We propose to pursue such a pathway through post-colonial theory which we now turn to.

\section{Post-colonial and neo-colonial theory}

Whilst multinational corporations (MNCs) have increasingly demonstrated the capacity to adopt appropriate management practices and to respond to the exigencies of the institutional context, there remain concerns about ethnocentricity, the attitudes exhibited by foreign managers, hence some marginalisation of local knowledge. While theories to explain this phenomenon abound, we find the emerging interest in post-colonial theory particularly appropriate in the African context. For example, Nkomo (2011) offers a postcolonial and anticolonial interpretation of representations of 'African' leadership. Yousfi (2013) draws from the post-colonial discourse on hybridity to explain how Tunisian managers modernised management through American methods. Jackson (2012) and Jackson et al. (2013) suggest that both post-colonial and dependency theory help explain the prevailing pejorative portrayal of African local or indigenous knowledge. Hence, the marginalisation of local knowledge, and the derogatory portrayal of Africa and African workers can be attributed to historical circumstances in which the dominant Western colonial powers imposed not only a political structure rooted in Western liberal democratic values but also a modernising management paradigm (Jackson, 2012).

This ethos has been identified in research that seeks to identify management practices that are not only contextually valid but which give voice to the African organisational actors (e.g. 
Blunt and Jones, 1992; Kamoche et al, 2004a). The term postcolonial refers to 'a period coming after the end of colonialism' (Childs and Williams, 1996:1). In political terms, it signifies the dismantling of structures of colonial control which characterised the 1950s/60s subsequent to which independence became a reality for many countries (Darwin, 1991). The 'period after colonialism' is of course a much broader historical phenomenon which spans much of the world, from Africa to the Americas and Asia, with European countries playing the role of colonising powers. The definitive feature of colonialism is the way it 'linked the West and its colonies in a complex structure of unequal exchange and industrialisation that made the colonies economically dependent upon Western colonial nations' (Prasad, 2003:5). Postcolonialism thus constitutes a radical critique of this historical enterprise.

Adam and Tiffin (1991) identify three forms of post-colonialism: the first considers countries/regions formerly under European rule; the second is conceived of as discursive practices, including resistance to colonialism and colonialist ideologies; the third strand refers to the persistence of colonialism, and the idea that Western powers are still intent on securing control over the former colonies. It is this mix of political, cultural and economic hegemony which has come to be associated with neo-colonialism (see also Childs and Williams, 1991). It is not surprising that various scholars within the post-colonial discourse see contemporary globalisation in Marxian terms as a new form of 'imperialism'. This argument is driven by the Mark-Engels view of capitalist intervention in the colonies as a quest for market expansion for goods and low labour costs (see Wallerstein, 1983). The post-colonial world can be characterised as 'paradoxical in-betweenness' (Spivak, 1990: 166) to signify a form of limbo in which a State might find itself, having overthrown the yoke of political colonialism but finding socio-economic independence elusive. Thus, African countries find they are endowed with vast resources, yet are unable to realise industrial and economic progress. China's entry creates a potentially mutually symbiotic relationship.

However, doubt has been raised about the extent to which African countries are benefitting from this engagement (e.g. Foster et al., 2008), hence leading to the suggestion that China's involvement in Africa is one of unequal partners, with the dominant party seeking a form of 'imperialist' control, where such domination might be characterised as the exercise of economic and political power without direct occupation (Prasad, 2003). By a similar token, Blunt and Jones (1997: 6) identify 'imperialist' tendencies amongst western firms in East Asia and Africa, in the form of domination resulting 'from an unequal distribution of power, usually associated with economic and technological superiority.' Whether Chinese firms are seeking 'imperialist control' or not is beyond the scope of our analysis; but we believe it is necessary 
to highlight the theoretical, management and policy implications of any apparent 'domination'. The fact that China's political-economy has been founded in a Marxist-Leninist-Maoist tradition that is fundamentally anti-capitalist and anti-colonialist (Young, 2001) provides us a unique opportunity to examine how such a historical background can be reconciled with an economic agenda and investment strategies that appear neo-colonial in character. Media pronouncements by Chinese authorities show China as particularly sensitive about suggestions of colonialism, and keen to emphasise 'partnership for mutual benefit'. Yet, various scholars (e.g. Kopinski et al., 2011) argue that these benefits do not reach ordinary Africans.

Some authors have suggested that post-colonial theory may not be appropriate for conceptualising the current geopolitical dynamics of China in Africa because there is not a post-colonial relationship between the two (see Jackson, 2012) and that the relationship was in fact built on an anti-colonial discourse in which China played a key role in supporting independence movements in countries such as Angola, Tanzania, Zimbabwe and Zambia (Snow, 1988). Hence, we consider the relevance of post-colonial theory with respect to Chinese managers' representation of 'otherness' (Bhabha, 1994) in their African personnel. Postcolonial theory proposes that the developing world is represented in the eyes of the developed world (Said 1978; 1995). The colonised are subjected to a questionable representation of 'otherness' yet are knowable, often via stultifying stereotypes and phobia (Bhabha, 1994). Thus, the former colony comes to see itself as under-developed, backward, needing help (in the form of aid and loans), and incapable of standing on its own feet, or exploiting its own natural resources.

More importantly for our purposes, the developing African country comes to view its own culture, values, knowledge and management practices as inferior to those of the colonising power, or in this case, the foreign investor. This perception of 'backwardness' ultimately legitimises the use of ethnocentric management practices. Ethnocentricity is defined as the tendency to view the world from the vantage point of one's own particular cultural or social group (Johnson et al., 2006). This view leads to overestimating the importance and worth of people in one's own group. An ethnocentric management approach may lead to the paradoxical position of local executives who identify the negative impact of ethnocentricity but feel powerless to act on it, thus failing to resist the dominance of the neo-colonial power. Moreover, foreign investors may disregard local knowledge, or consider local skills as inadequate and inappropriate for their advanced technology and insist on bringing their own workers in addition to expatriate managers. 
In the transfer of management practices, ethnocentricity may become self-perpetuating, and the local knowledge possessed by local managers and that can be utilised to achieve better firm performance may be neglected. Thus, ethnocentricity may not only create frustration for local managers but can also become a barrier to firm performance. Yet, resistance to the dominance of the unequal partner is considered a vital aspect of post-colonial thinking (Childs and Williams, 1996). We argue therefore, that where ethnocentric practices with a neo-colonial character are resisted or questioned, we can infer a post-colonial ethos in unravelling the nature of the business relationship irrespective of the pre-existence of a colonial political one.

\section{Methodology}

\section{A qualitative approach}

With respect to Africa-China relations, Jackson (2012) argues that the sheer lack of empirical data requires in-depth interrogations of China's motives at the organisational level, as well as the cultural influences. In order to gain as complete a picture as we could about the nature and scope of the phenomenon in question, we opted for a qualitative methodology embracing several approaches that we felt would best capture the realities and 'stories' of the social actors. Given the complexity of the phenomenon in question which potentially lent itself to multiple interpretations, we were guided by a key question: 'what's the main story here?' (Strauss, 1987). Gaining an in-depth understanding (Hollis, 1994), i.e. deep knowledge of an unravelling phenomenon as opposed to a static snap-shot at a point in time (Ragin, 1994) was a defining feature of this undertaking.

Following Schofield (1993) we took the view that this work would be valued for its 'intrinsic interest' as well as for the substantial and novel insights it would generate with a view to contributing to theory-building. In line with Dyer and Wilkins (1991) and Yin (1994), we sought to contribute to theory-building through an analytical approach that allowed the social actors to tell their own stories, unfettered by any preconceived notions the researchers might have harboured. Qualitative approaches have proven to be appropriate for researching comparable phenomena in the African context (e.g. Jackson et al., 2008; Opondo, 2009; Idiagbon-Oke and Oke, 2011). To achieve our research objectives, it was necessary to talk to both the Chinese investors/employers as well as the Africans who work for them. This is in contrast to much extant Africa-China research which has relied on secondary data, economic/trade statistics and survey data (e.g. Drogendijk and Blomkvist, 2013). We encountered substantial challenges in negotiating access with firms that were not only unaccustomed to academic research but had also become extremely circumspect about 
perceived 'harassment' by local bureaucrats and government officials in the guise of ensuring compliance with local laws.

\section{Data collection and analysis}

The interviews were conducted by both authors, a Kenyan and a Chinese, each with a deep understanding of their respective country, on separate occasions during a three year period from 2011 to 2014. We conducted 71 interviews with 62 people $(n=62)$ : 30 Kenyan, 31 Chinese, and 1 Nigerian. The details are summarised in Table 1. Seven people were interviewed more than once on subsequent visits. A total of $29(n=29)$ Chinese organisations were covered, in sectors ranging from engineering, mining and construction, manufacturing, trading, media, catering outlets, to non-profit, and travel. Most were privately-owned, and would not disclose details such as size, ownership and business performance. They ranged from large conglomerates to small and medium-sized firms. We also interviewed a range of stakeholders who had some interest in the subject, including five Kenyan entrepreneurs who had business dealings with Chinese firms, one lawyer who had a large number of Chinese clients, and four senior Kenyan public officials.

\section{Insert Table 1 about here}

We maintained contact with some of the interviewees and followed up with interviews on subsequent visits, and through telephone conversations, thus helping to fill gaps, enhance our knowledge of an unfolding phenomenon, and double-check our findings/interpretations as the interviewees were unable to devote time to review the transcripts. Over time, the project began to assume the character of a longitudinal study. Access varied from firm to firm, and while we sought to interview at least one person in each firm, we managed to interview at least a Kenyan and a Chinese in each firm. In some cases there were two to three interviewees and as many as eight (five Chinese and three Kenyans) in one conglomerate. Some Chinese managers did not permit access to Kenyan staff, while in some cases we managed to speak to Kenyans but Chinese declined to participate. This did not pose a serious problem as our purpose was not to juxtapose the views of the respective parties. We began the initial search by consulting records of Chinese firms from relevant government departments, the Chinese embassy in Nairobi, and through personal contacts. In the majority of cases, the Chinese declined to participate, offering a variety of reasons, including time pressure and suspicion about the real purpose of the research. 
Some of this mistrust has been attributed to cultural issues: Chinese have apprehension about talking to 'outsiders' (Siebers, 2011), as well as perceived 'harassment' by bureaucrats and law enforcement officials searching for illegal workers and inspecting trading licenses. The challenges of conducting research in an African context (Kamoche et al, 2004a) were compounded further by the subject matter, requiring us to exercise even more resourcefulness. Therefore, out of the 71 interviews, we conducted 53 (75\%) ourselves and the other $18(25 \%)$ were conducted by a research firm (eight Kenyan and 10 Chinese). The firm in question was given a very detailed brief with specific questions identical to the ones we ourselves asked. They were asked to interview 10 Chinese and 10 Africans; 18 were usable. After we jointly identified and agreed the sample, we independently confirmed the identity of the contacts, vetted and trained the interviewers, and verified the digital recordings.

While asking very specific questions, we relied on open-ended semi-structured interviews (Gillham, 2000), in which the interviewees were allowed to speak freely, prompted with appropriate probing questions. Kenyan employees and supervisory personnel were asked about their motives for and experience of working for a Chinese company, and their perceptions of Chinese business practices. Chinese investors were asked about their motives for investing in Kenya, the support and challenges they have gained and faced respectively, their perceptions of the Kenyan workforce, and how they deal with human resource and cross-cultural issues at the workplace. Other Kenyan interviewees, such as entrepreneurs, media and legal personnel were asked questions about their relations with Chinese organisations, and their observations of the public perceptions of the Africa-China phenomenon. Public officials were asked about the official policy on Chinese investments, the State's view on the controversy surrounding these investments and what they saw as the future of this engagement.

The majority of the interviews with the Chinese were conducted in Mandarin; those with Kenyans were conducted in English. While all the interviews relied on detailed note-taking, half of the interviewees agreed to be digitally recorded. Further notes and reflections were prepared immediately after each interview in order to benefit from fresh memory (Whyte, 1994). Following Jackson et al. (2008), all sets of notes were carefully compared for consistency and reliability, and irrelevant content deleted. The recorded interviews were transcribed and those in Chinese translated by a professional translator/transcriptionist, and subsequently checked for consistency against the original recording by the Mandarin-speaking author and an independent third party. Making sense of the extensive amount of data involved an approach consistent with narrative analysis and interpretation (Gabriel, 2000; Pinnington et al., 2009) at the level of the social actor's individual's experience, and with reference to a 
diversity of organisational forms. The transcribed responses were checked against the recordings and field notes by both speakers in the respective language, coded according to topic and subjected to a series of iterations until specific themes and stories began to emerge. These themes and stories were corroborated against each other and double-checked against the field notes, thus ensuring the integrity of the data. Follow up contact with interviewees also helped ensure validity of interpretation. Our analysis was guided by replication rather than sampling logic (Dyer and Wilkins, 1991; Eisenhardt, 1989; Yin, 1994), and aimed to critique and extend existing theory rather than to test it. We constantly re-examined the transcripts in the light of the emergent themes and new interpretations to seek both verification and contradiction (see Richards and Richards, 1994).

\section{Findings}

Our analysis generated four key themes which we discuss below under the following sub-titles: the diverse drivers of Chinese investments, the challenge of reconciling cross-cultural differences, the impact of low-cost strategies on the management of human resources, and the boundary-spanning role of local managers. Taken together, these themes characterise the nature of Chinese investments in Kenya and have important implications for Africa-China business relations in general and our research questions in particular.

\section{Drivers of Chinese investments and motivation to remain}

In examining the motives for investing in Kenya, we sought to interrogate the general perception that Chinese firms are engaged in a State-sponsored strategy to secure domination over African markets. While this reasoning might apply to some of the large State-owned firms that have been winning tenders in major infrastructural and mining ventures, the reality for private firms and SMEs is much more nuanced. This project revealed that although the number of Chinese investments is small in relative terms as compared to western firms, there has been a steady stream of Chinese investors into Kenya over the years, with the Chairman of the China Kenya Association (CN14, Director, Conglomerate) himself having started his businesses thirty years ago.

While resource-seeking largely explains the behaviour of large SOEs, the entry of private firms and SMEs can be categorised into two: (a) those who deliberately sought international opportunities out of genuine concerns about the viability of the Chinese domestic market, and (b) those who ended up investing in Kenya as a result of a combination of opportunism and serendipity without a grand investment strategy. Both categories often made the decision to 
invest and live in Kenya in the face of strong opposition from friends and family. Many of these individuals report being attracted to the mild climate, fresh air and relatively wellmanaged ecosystem (an obvious comparison with major industrial Chinese cities), the friendliness of the local population and the relatively stable political climate. Challenges for the Chinese firms included: insecurity, poor infrastructure, fluctuating exchange rates and perceptions of the lack of a highly-committed and competent labour force. The comment below typifies the case of investors who were driven by concerns about China.

I came to Kenya because I was not sure what the economic reforms in China would bring us and I have stayed and lived here for three decades because I thought I had already come here and I must persist in my work here and I have been here for more than 30 years ... (CN14, Director, Conglomerate).

In an analysis of the internationalisation of Chinese firms, Child and Rodrigues (2004) argue that Chinese firms seek competitive advantages in new markets instead of exploiting competitive advantages in the domestic market, which they achieve by seeking technological and brand assets. Our findings echo Boisot and Meyer's (2008) view that the internationalisation of many Chinese firms presents strategic exit rather than strategic entry into foreign markets. The opportunistic investors present an equally interesting picture:

I ran a business in Kuwait before, so I had some experience of living abroad, but coming to Kenya was a big challenge. I got the idea from a friend who was working here, but many friends and family couldn't understand why I wanted to come here. So I had to work very hard to prove myself (CN2, Entrepreneur, Catering).

I was going to England to study but my brother told me that there were good opportunities in Kenya and I came to help him. By now, we have worked here for twenty years and we run large businesses across various sectors (CN15, Director, Conglomerate).

Many who had misgivings soon found the country very accommodating. (CN24, Deputy General Manager, SOE, Construction) found the country 'was not as bad as I'd imagined.' For the majority of Chinese managers/investors living without family, adjustment/adaptability is a 
major challenge, necessitating home return once or twice a year. The high cost involved in part explains why Chinese expatriates are kept to a minimum and why the claims of importing vast numbers of Chinese labourers do not ring true. Doing business in Africa was, in the main, less stressful than many previously imagined. Ironically, some saw benefits in potentially problematic areas as in the surprising confession below:

... Corruption is beneficial to us. Take a simple example of processing immigration documents. Give the local official a small tip, and he'll settle it for me ... it's more serious in China. Indeed they ask for less money here (CN24, Deputy General Manager, SOE, Construction).

The manager reported that officials were happy to accept bribes but insisted their company followed regulations in bidding for projects. The scope and effect of corruption is a matter of perception and personal experience, as other managers reported that at least at the level of petty officials, corruption in Kenya was 'worse' than in China. As for those who are deployed as expatriates, especially by SOEs, the element of choice is absent, but they too had little difficulty in adapting.

... Since we are employed, and deployed by the company, we have no choice where we want to go. But after coming to Kenya, I feel that Kenya's climate is good, the people are friendly ... and the entire political situation is stable, and I've made a lot of local friends (CN18, Chairman, SOE, Construction).

I came to Kenya as a General Manager sent by our company's Headquarters back in China. I was responsible for our US market before. Our company has been operating in Kenya for thirty years and surely we will strengthen our development in this rapidly growing market (CN26, Managing Director, SOE, Construction).

An executive (CN24, Deputy General Manager, Construction) at a SOE involved in infrastructural construction reported that the company first got involved in Kenya by participating in a World Bank funded financial aid project, and then chose to stay on to pursue other commercial projects. This company also reported that Kenya provided various forms of incentives in the early days but as competition intensified, these dried up. Virtually all the firms 
reported that they received no preferential treatment, and most lamented that this compared unfavourably with the tax breaks afforded to foreign firms in China. Yet, this did not present a serious disadvantage, nor did the challenges noted above particularly alienate Chinese investors. The comment below exemplifies the common view about wanting to be a part of Kenya's/Africa's economic rejuvenation, and acknowledging the continent's potential:

Kenya is our home. We are proud of our own country China's development and we appreciate how China has been growing into a big economy. We hope Kenyans will do the same for their country and we are here to help them to do it as well. We hope Kenya will have a strong financial basis and good prospect in future (CN29, Marketing Executive, Pharmaceuticals).

The foregoing challenges the conception of a homogenous China, and demonstrates that the motives of Chinese firms' engagement in Kenya are not limited to asset and resource seeking (Kurlandtzick, 2006; Gill, et al., 2007; Drogendijk and Blomkvist, 2013). While Li et al (2013) have found that the Chinese acted to represent the interests of firms in the natural resource sector, our findings are consistent with Brautigan and Tang (2011) who found that the Chinese government's role in creating special economic zones in Africa was limited to the initial diplomatic deliberations, after which the companies became the main actors.

\section{The challenge of reconciling cross-cultural differences}

This theme captures the difficulties individuals in both communities perceived through their joint interaction. We sought to understand the basis of the stereotypes and misconceptions, and the effect these had on workplace relations. The general perceptions Kenyans harboured ranged from suspicions about Chinese wanting to 'take over Africa', hiring large numbers of Chinese workers, using Chinese prisoners on construction sites to keep costs down and under-cut rivals, to the more positive perception of Chinese managers as caring and understanding. The latter view was based on the assumption that managers from a developing country like China have empathy with the day-to-day problems faced by low-wage workers. However, there were issues of communication and language skills which may have caused misunderstanding.

Chinese understand African workers' problems but should learn English for better integration (KN2, Business Supervisor, Catering). 
They are good. They're kind-hearted, but not all ... [compared to Indians] who have a bad perception of Africans (KN16, Office Coordinator, Conglomerate).

Everything is kept very simple. They don't even advertise at all, even on billboards, TV, radio, etc. It's ignorance. (KN2, Business Supervisor, Catering).

They don't speak much English but train themselves on the job. It can be a problem (KN17, Sales Manager, Conglomerate).

Some of them have a tendency of being quite rude, and speaking very loudly. I don't know if it's a tactic to intimidate, and some can really scare you. But you get used to it and learn to adjust. The first two months I was asking myself why I'm working here, but got used to brushing it off (KN18, Travel Consultant, Conglomerate).

We sometimes have this problem in the office - after lunch, the Chinese take a nap. Kenyans might think that's the time to play music loudly (KN20, Deputy General Manager, High-tech firm).

Not surprisingly, Chinese managers held mixed views about Kenyan personnel (both workers and managers). However, while they generally expressed satisfaction with managers whom they considered essential as discussed in a section below, the consensus about workers was mostly negative. The selected quotes below illustrate this:

The country has lots of blessings but people take these for granted, they give up easily (CN14, Chairman, Conglomerate).

HR in Kenya is very good compared to neighbouring countries. Kenyans are very hard-working (CN21, CEO, High-tech firm).

Kenyan workers have a lower level even when we are talking about skilled workers. They still don't measure up (CN18, Chairman, SOE, Construction). 
Chinese workers are like balls, if you kick them, they will run for a certain distance; the Kenyan ones are like a square, if you kick them, they go one step further, then they stop and wait (CN29, Marketing Executive, Pharmaceuticals).

A common complaint was that Kenyans do not like working overtime, do not want to work on weekends, and also do not work efficiently because of their low skills and attitudes. Some Chinese attributed this practice to the British colonial influence which they believe did not instil a work ethic and concern for efficient, quality performance but instead created a culture in which African workers were reduced to a servile role.

How can you rest on Sundays if you can't even make ends meet? How can you justify it? (CN25, General Manager, SOE, Construction).

One manager (CN23, Assistant General Manager, SOE, Construction) acknowledged that the situation did not warrant change as Kenyans have to go to church on Sunday and cannot be coerced to work. The business culture presented some challenges particularly for those in the private sector who expected incentives in order to invest as was the case in China, but found foreign firms did not receive preferential treatment. A number recalled that investment incentives were once available when Kenya actively courted FDI two decades ago, but these supposedly dried up over the years, creating particular challenges for Chinese SMEs. In contrast, managers of SOEs felt that although there were no specific incentives, subsidies or tax breaks, they did benefit from the favourable treatment accorded Chinese investors in Kenya's 'go East' policy.

We identified two additional yet inter-related problems which have not been acknowledged in the existing literature: the perceived absence of reciprocity, and the effect of cultural incompatibilities on trust-building. The Chinese often adopted a paternalistic approach whereby they believed they were 'looking after' workers by allowing a generous amount of leeway in the event of employee tardiness and inefficiency, as well as providing various forms of welfare benefits for employees in need. In return they expected employees to reciprocate by working hard, and to sacrifice their free time to work overtime when necessary. Paternalistic management is relatively common in Kenya (Kamoche et al., 2004b). Yet, when Kenyan workers failed to demonstrate the expected commitment, Chinese managers concluded that this 
form of reciprocity did not apply to Kenyan workers. Some of these views echo the more extreme ones expressed in an earlier era by western settlers and expatriate managers who complained about lazy, carefree Africans and were often racist and intolerant (Onyemelukwe, 1973). Researchers have sought to explain the African worker's ambivalence toward the exigencies of an industrial lifestyle in terms of the deprivation of ownership rights, low empowerment and employee involvement which in turn undermine employee sense of belonging, ultimately generating a low level of commitment (e.g. Ukaegbu, 2000; Judith, 2012). Lack of trust presented a particularly serious problem for Chinese investors accustomed to sealing business deals with limited formal procedures or paperwork. Their approach to business might be described as 'flexibility based on trust'. According to a Kenyan lawyer (KN19), the failure to formalise agreements through established legal procedures often meant that Chinese investors sought legal help when the damage had already been done.

Chinese invest in all sectors and they face counterfeit product problems. In addition, Chinese companies sometimes do not all follow laws and regulations and they only look for a lawyer when the problems have already occurred' (KN19, Business Owner, Lawyer).

A similar phenomenon has been observed in Zambia where Chinese begin to implement projects rapidly and only carry out research later as and when necessary (Hagland, 2009). Asked what the government was doing to ensure job-creation by Chinese firms and to tackle the problem of illegal workers, a government official saw the issue in terms of poor communications, a view that reinforced the ambiguity surrounding official policy:

The Chinese do not always communicate their needs well. They have a language crisis, so they would rather try to let you know once they get here what their requirements are, but they should have done it prior to arrival. (KN23, Government Official).

Various Kenyan managers found that Chinese investors did not always honour their 'flexible' approach, when agreements were subsequently changed unilaterally, thus undermining trust. This was particularly noteworthy when it came to employment terms, as discussed below. This is attributable to the effect of culture on the way Chinese people think and communicate, with a 'pictographic language' that emphasises the big picture instead of 
exact details (Graham and Lam, 2003). Although African speech patterns have traditionally been characterised by anthropologists as relying on symbol, metaphor and non-verbal forms of communication (Gudykunst et al, 1996), urbanised Kenyan workers and managers appeared to expect a high degree of precision.

\section{The impact of low-cost strategies on HRM practices}

In our effort to characterise the human resource practices used by Chinese firms, one theme appeared dominant: their reliance on low-cost employment strategies, in particular the absence of advertising in recruitment, little use of formal, 'time-consuming' recruitment practices to an emphasis on low wages. Educational qualifications and previous experience were generally ignored at lower supervisory and ordinary employee levels, and the most sought-after qualities were honesty and punctuality. The rationale for informal word-of-mouth hiring found some justification in the high unemployment rate in the country. It was not only the low-skilled poor workers who flocked to Chinese firms. Powerful individuals also saw Chinese firms in general as an opportunity to discharge family pressure obligations through informal networks:

\footnotetext{
See, once your company starts recruiting, people with connections start knocking on your door ... especially government officials. 'Oh, can my relative come and work for you?' That kind of thing. (CN14, Director, Conglomerate).
}

The low-cost employment strategy generated several problems. In particular, a low wage regime (based on the perception of low skills, inefficiency and poor work ethic) does not necessarily attract the best candidates, and in fact becomes a self-fulfilling prophecy. It transpired that the educational level of many employees, especially those in construction, was rudimentary, which in part explains much of the stereotyping. In the majority of cases, hiring through word-of-mouth was based on the belief that employees would only recommend trustworthy friends and relatives who would feel compelled to live up to expectations if for no other reason than to protect the recommender. Chinese managers were quick to dispel the 'myth' that they relied heavily on Chinese workers. The hiring of Chinese personnel was determined by the nature of the jobs: construction firms, be they private or State-owned, were more likely to hire relatively more technical staff including engineers, and not low-skilled Chinese workers. For jobs such as travel agents, it made little economic sense to hire Chinese with little knowledge of the local terrain, literally and business-wise. 
Only for specific kinds of work that we cannot find workers here would we bring in some from China (CN18, Chairman, SOE, Construction).

On the claim that Chinese companies hire 'cheap' convicts and hordes of Chinese workers: Chinese workers can endure hardship, and are willing to endure hardship ... the general public here recognise that Chinese people are quick and cheap in repairing roads, although there are people who speak against the Chinese companies and denigrate their image by saying that they have brought prisoners ... I ask them, "where do you get your idea of "reform-throughconvicts?"' (CN14, Director, Conglomerate).

After explaining how Chinese firms price the labour and the high costs (double the wages, visa fees, accommodation, home passage etc.) associated with bringing workers from China, the investor explained:

This is as clear as daylight. Even dummies can work that out. If you came from America to set up a factory here, would you bring American workers here? That's impossible (CN14, Director, Conglomerate).

The foregoing is consistent with Brautigan and Tang's (2011:45) findings that contrasted with 'popular accounts that assume Chinese projects bring in all their own workforce'. Our position also echoes Davies et al.'s (2008) argument that it may appear that Chinese companies import manual labourers, but in reality, skilled workers are brought in to fill specific gaps. A more direct outcome of the low-cost employment strategy was low wages. Chinese managers found it difficult to understand why financial incentives offered through overtime and weekend work did not appeal to Kenyan workers.

It was very difficult to ask them to work overtime in the beginning when we first built roads here. Nobody would come. Of course overtime wages are very high, 1.5 times on Saturdays and double for Sundays ... their market concept has changed. Let's say if you never show up, I would not hire you again ... We have to follow our plans and schedules. If you cannot fit in our schedule, you'll be eliminated (CN18, Chairman, SOE, Construction). 
The above statement typifies an aspect of Chinese culture that goes beyond 'diligence' to 'endurance' - chiku nailao (吃苦耐劳), and is considered to be more important than talent. Hard work even in the most difficult conditions is considered honourable in Chinese philosophy (Graham and Lam, 2003). The Chinese took the view that Kenyan workers did not exhibit this tenacity.

The majority of Kenyan employees reported being unhappy with the wages relative to what they might have earned elsewhere.

Kenyans don't like working for Chinese. The pay is no good. Overtime is not attractive. They're too mean. Even to get a Chinese to give you a tip, it's a problem. They never give tips (KN2, Business Supervisor, Catering).

Chinese pay well when they first come, but as they take root they tend to reduce the pay. That is not very good. They come as visitors and try to endear themselves to the locals, and over time they tend to change although legally they're not allowed to do that (KN17, Sales Manager, Conglomerate).

I am not too happy with the pay, but it's okay for now. But I still want to work here. The boss is good, and sympathetic. Anyway, inasmuch as they're domineering, they give you space to exercise your discretion (KN18, Travel consultant, Conglomerate).

The foregoing can be explained with reference to culture and cultural differences. It is not the Chinese practice to give tips even in restaurants. Instead, workers may receive red packet money, i.e. 'hongbao' (红包) for good performance, particular during festive seasons and special occasions (see Hurst, 2009). While overtime rates were not perceived by Kenyan workers as particularly attractive given the relatively low base-rate, this phenomenon had some notable implications for trust-building, from the point of view of Chinese employers, who appeared oblivious of the impact of a low-wage strategy.

You don't have to pay them too much. However, if you leave an amount of money three times as much as his salary, he will immediately grab it and run 
away ...you can say that they steal because they are poor (CN25, General Manager, SOE, Construction).

A small number of firms focused on service-delivery based on high-level expertise, thus demonstrating that goal-focused strategies did exist alongside low-cost employment strategies.

The highest position of Kenyan workers is Supervisor. It is not easy for Kenyans to be promoted because most of them are low-skilled; however, there are very good Kenyan workers and these workers get paid even more than any other Chinese workers (CN18, Chairman, SOE, Construction).

Everyone is equal in our company. There is no guanxi network here and the most important thing is to deliver. One can argue with me, as the CEO, but if he can deliver what is required, then he is right. We will forget about the arguments we had (CN21, CEO, High-tech firm).

The forgoing illustrates the diversity of corporate culture and management styles of individual Chinese firms and their impact on human resource management practices.

\section{The boundary-spanning role of local managers}

In spite of the rapid advances in human resource management (HRM) (e.g. Kamoche et al, 2012), there has been relatively less attention on managers, in particular the recruitment of managers, the development of managerial expertise, and the role of local managers in MNCs from emerging economies (see Engardio, 2008; Thite et al, 2012). China's own experience of industrialisation and modernisation may have vital lessons for Africa (Jackson, 2012). The concerns about hiring employees were also mirrored in the hiring of managers, suggesting that there was still an over-reliance on senior Chinese personnel while local expertise was available.

There are guidelines about management structure. The most important positions are given to the owner. The others should be shared equally between the two, and a Kenyan should be given priority, but it's not always followed (KN1, Assistant General Manager, Service).

This manager explained the practice as follows: 
It is to do with trust - they might not trust locals. It is normal to offer a job to someone you think will not let you down (KN1, Assistant General Manager, Service).

While local managers and supervisory staff were mostly hired through formal recruitment mechanisms including advertisements in the media, the informal approach through word-of-mouth noted above also extended to these cadres, particularly in engineering/construction firms.

At the end of a project, engineers would recommend one another. And graduates of one university may recommend graduates of their university (CN18, Chairman, Construction).

Recruiting competent managers was not as challenging as hiring competent employees, as the former were able to offer high educational credentials and appropriate experience. Retaining them, however, often proved problematic, and according to one Chinese manager (CN25, SOE, Construction), the challenge was to find highly-skilled professionals who desire paid employment as many senior engineers reportedly opted to set up their own businesses at some point. One telecommunications firm gave up recruiting experienced managers and preferred to hire graduate trainees, including Kenyans who had studied in China or taken Chinese language courses at a local university, thus adding a cultural angle to the notion of boundary-spanning. Kenyan managers on the whole expressed satisfaction with Chinese firms, which largely contradicted the public's general perception.

I am happy here. The Chinese treat us well. For us here, we have a Chief Accountant. In the construction industry ... most of the Chinese people are engineers, so you find they are in better positions (KN16, Office Coordinator, Conglomerate).

Opportunities to advance are quite many as Chinese firms expand. They are changing the way people do business here. They have made business construction affordable by bringing down prices, though there are quality issues. In terms of how they treat people, not bad, but not 100\%. I would give 
them 70\%, an Indian employer 55\%, a Kenyan employer 75\%, and British 80-85\% (KN17, Sales Manager, Conglomerate).

This latter manager (KN17) reported being 'quite happy' after five years working in a Chinese construction company and said he was aware of 'many Kenyans' in management positions in Chinese firms. The main challenge for local managers was a glass ceiling as the senior positions were generally reserved for the Chinese. This was particularly frustrating for managers who only discovered late into the selection process that the employer was Chinese, in organisations that did not use a Chinese trading name. For many, the feeling of being consigned to the periphery remained, even if locals could rise to senior positions such as Department Manager or Chief Accountant:

They are not open to Kenyan engineers and do not allow them to have access to the computers Chinese engineers use (KN8, Manager, SOE, Construction).

The attitude described above demonstrates both a general lack of trust and limited opportunities for empowerment and decision making for local managers. This marginalisation of local managers raises doubt about the commitment of Chinese firms to foster and enhance managerial expertise. Local managers also complained about not being fully involved in decision-making, or having decisions over-ruled, which undermined trust.

I'm proud of the fact that I developed an accounting system here. The place was a mess before. Anyway, I expected the MD to approve it, but he came up with something slightly different. He wants to feel he came up with the idea. He appreciates the protocols and system but wants to make the idea look like it's his own (KN1, Assistant General Manager, Service).

The MD's behaviour can be interpreted as wanting his employee to give him face, i.e. mianzi (面子), (see Graham and Lam, 2003; Wang et al., 2005), in order to demonstrate his power. This resulted in bewilderment and a possible impact on morale. 
They change very fast. You can decide on something and the next minute they've changed it. You can make a decision today, and tomorrow it's all changed (KN17, Sales Manager, Conglomerate).

A key observation was that Kenyans are hired to facilitate interaction with various stakeholders and for their knowledge of the institutional environment, which highlights the significance of their boundary-spanning role in their interaction with employees, clients and authorities. This continues a long tradition by western firms of relying on locals to negotiate the institutional bureaucracy while doing little else to advance their career opportunities (e.g. Henley, 1977; Langdon, 1981; Kamoche, 2000).

We have five to ten per cent (Kenyan managers) ... they each have their own strengths. A local manager can communicate more easily with the local staff ... Also, he's more familiar with the administration of the local government ... local administration, procedures, the different departments, their regulations, etc ... and he knows where to find resources $(\mathrm{CN} 23$, Assistant General Manager, SOE, Construction).

We Chinese don't actually supervise Kenyans to do their work, but rather, we teach them. The actual supervision is done by local group leaders. The middle and senior management positions are all held by the Chinese. That's the general practice (CN25, General Manager, SOE, Construction).

Over time, after gaining operational experience in the Kenyan market, Chinese managers learn the need for empowerment and trust-building if they are to depend on local managers. As one executive reported:

As managers, we are getting more and more familiar with Kenyan colleagues and we trust and tolerate each other more. We have a non-smoking policy in the company, but my colleagues tolerate me when I smoke ... and we do empower Kenyan employees... the highest position a Kenyan holds here is Deputy General Manager, who has been working in the company for 12 years (CN21, CEO, High-tech firm). 
The executive saw this kind of 'tolerance' as the beginning of effective interpersonal relationships between these two parties, a view that can potentially challenge the culture of mistrust and misconception noted above.

\section{Implications}

This section discusses the extent to which our key research questions have been addressed by the findings above. We structure the discussion in terms of our three questions.

\section{Re-examining presumed homogeneity}

The findings suggest that the general perception of 'China' as a homogenous power controlling and driving investments needs to be treated with caution. While this argument might capture some of the strategic drive behind SOEs, it has little relevance for private firms and small proprietorships that constitute a visibly significant presence in Kenya and yet do not receive any direct support from China. Chinese investment is multi-faceted and multi-voiced. It could be argued however, as one investor pointed out, that private firms and SMEs do benefit indirectly from the Chinese economic reforms which have resulted in Chinese manufacturing achieving global respectability (CN30, Marketing Executive, Pharmaceuticals), and from the espoused 'go East' policy. This is a far cry from a putative State-sponsored conspiracy. Evidently, the range of drivers of Chinese investments in Africa, with particular reference to Kenya, is not confined to asset or resource seeking as suggested in some of the literature (e.g. Drogendijk and Blomkvist, 2013), or political intention as contended by Gill and Reilly (2007). In reality, the organisations see themselves as competitors, even more so if they are in the same industry, bidding for the same project contracts. At the social level, the Chinese see themselves as a community, as one of the interviewees commented: 'The competition is very high... But mostly we cooperate with each other. We do help each other because we are all Chinese, we are a Chinese community' (CN19, Administration Manager, SOE, Construction).

The diversity of motives in turn mirrors the diversity of approaches to the management of people though there is much convergence particularly due to the nature of the culture from which the firms emanate, which in turn shapes the managers' attitudes towards Africans. This argument has important implications for the range of stakeholders with an interest in Chinese firms, from job-seekers to prospective investment partners and policy-makers. Taking the key consideration into account - remuneration - from the research findings there did not seem to be any significant differences in the levels of remuneration. The firms in our sample displayed extensive diversity in management practices. These practices were underpinned by a drive for 
competitiveness in a difficult business environment in which they all struggled to secure contracts, market share and talent. This contrasts with Ding et al. (2007) who reasoned that Chinese privately-owned listed firms favour earnings boosting methods more than SOEs. We found no such distinction. We did find however, that privately-owned high-tech firms (as reported by CN21 (CEO, High-tech firm) were more prepared to empower locals, and less reliant on interpersonal relationships and were therefore more inclined to adopt flexibilityorientated HRM systems in line with the findings of Chang et al. (2013).

Virtually all the firms were considered (by both the Chinese and Kenyans) as pursuing a low-wage strategy particularly in terms of the recruitment process which relied heavily on personal connections and word-of-mouth. This observation is in line with Peng and Luo's (2000) argument that Chinese managers have a cultural propensity to rely on informal ties and personal connections. Prospective local investors and policy-makers would find a higher level of formalisation and propensity to comply with the law among SOEs and large private firms as opposed to SMEs which tended to rely on informal practices and trust but often found this did not work as well as it did in China.

\section{Utilisation of local knowledge}

In terms of responses to local knowledge, an emergent body of knowledge suggests that firms that invest in Africa must not merely concern themselves with injecting much-needed capital and creating employment but should also transfer knowledge and enhance local skills and managerial expertise (e.g. Asiedu 2004; Dupasquier and Osakwe 2006; Kamoche and Harvey, 2006). To this research agenda, we posit the need for MNCs to learn from the local context not merely for the sake of institutional isomorphism (DiMaggio and Powell, 1983) but also in order to develop practices that are more contextually valid. Yet, prior research has noted the prevalence of ethnocentric management practices by Western firms operating in emerging economies, including China (e.g. Johnson et al, 2006; Gamble, 2010; Siebers, 2012), in the belief that these practices are superior to whatever knowledge is available locally. The issue for us here is to what extent are Chinese firms basing their business and management practices on similar assumptions? We argue that by hiring local managers as boundary-spanners, Chinese firms are acknowledging the imperative to seek local knowledge, particularly where these boundary-spanners are interacting with key stakeholders including policy-makers. This finding is consistent with the Kamoche and Harvey's (2006) argument about the role of boundaryspanners. The challenge remains whereby managers feel marginalised as noted above, raising 
doubt about the impact of ethnocentricity. The use of skilled, knowledgeable local managers is, we believe, a more credible illustration of the utilisation of local knowledge as opposed to the use of local employees with generic skills. Our findings on the hiring of locals are consistent with $\mathrm{Gu}$ (2009), who states that once operations are established, the majority of the employees are hired locally. That in itself does not, however, guarantee utilisation of specialised local knowledge where the work is routine and low-skilled. At the professional level, there is much more scope to draw from local knowledge amongst employees in firms that de-emphasise interpersonal relationships (CN21, CEO, High-tech firm).

The practice of disregarding local knowledge or 'ignoring laws and regulations' according to a Kenyan lawyer (KN19, Business Owner, Lawyer), and seeking legal advice as a last resort would appear to demonstrate a belief (often unwarranted), in the effectiveness of their own knowledge and business practices, and ipso facto, a tendency to undervalue local knowledge. This is also implied in Gu (2009) who found 'weak linkages' between Chinese firms and local African firms. Moreover, the Chinese practice of relying on trust and tacit agreements (Chen et al., 2004) rather than only formalised procedures, while crucial for the effectiveness of Chinese business, may not be completely suitable in this context if trust has not been established. Thus, there is a need to build trust and seek to gain a thorough understanding of the institutionally valid local knowledge. Similarly, a better understanding of Chinese culture, philosophy and management practices may provide more opportunities for career progression of Kenyan employees and more effective partnership between Chinese and Kenyan organisations.

We argue, however, that local knowledge should not be treated as sacrosanct, and scope must exist for appropriate learning to take place. It is necessary to make a distinction between gaining an awareness of extant norms and practices on the one hand, and actually applying them, on the other, especially when they involve potential illegality, such as corruption. Chinese firms were prepared to apply whatever practices delivered desired outcomes, which meant being prepared to engage in graft, or changing business and management practices, such as building roads at night, and changing entrepreneurial attitudes through their willingness and ability to invest with a high degree of flexibility. A Kenyan employee commented:

'We were never a 24-hour economy but slowly we are adapting to that ... One thing about the Chinese, they are very sensitive on targets and timing. They know any carryover expense would be a bad thing at the end of the day. So, 
if they can get things done, why not use all means to get the things done?' (KN19, Business Owner, Lawyer).

Chinese were also prepared to learn, and in some cases, acknowledged the limits of ethnocentricity.

'I have learned a lot from Kenyan people, not only English language but also the patience they gave me particularly when I came to this country, and I learned from them what love is[from God], and their kindness and simplicity make our workplace a harmonious environment' (CN15, Director, Conglomerate).

Thus, while China's pursuit of economic development involves a process of learning, selective adaptation and innovation due to uncertainties in each country (Lin and Wang, 2012), there is a need to examine cross-vergence and possible hybridisation (e.g. Azolukwam and Perkins, 2009; Horwitz et al., 2002), in the formulation of blended business and human resource practices, thus fostering mutual learning.

\section{Re-examining the post-colonial critique}

This theme sheds light on the extent to which the Africa-China engagement exhibits an economic neo-colonial character, and the suitability of post-colonial theory in this discourse. Africa's experience of colonialism was one whereby Western powers did little to develop sustainable economies based on manufacturing and processing raw materials domestically. The colonial approach focused on extracting raw materials and (largely unprocessed) agricultural produce for European economies and consumers. Critics see a parallel with the Chinese extraction of oil and minerals, and in this regard this paper highlights an important connection between post-colonial theory and current management practices. With respect to construction firms undertaking major infrastructural projects, we argue that the construction of road networks ultimately contributes to economic sustainability and self-reliance, the antithesis of 'imperialist'/neo-colonial economic subjugation. However, the reliance on foreign firms to drive economic growth while failing to foster managerial expertise could potentially undermine the portrayal of Chinese firms are a partner in Kenya's economic rejuvenation.

As the era of colonialism and forced labour came to an end, global capitalism assumed a new complexion as MNCs relocated factories to lowest-cost labour zones (Childs and 
Williams, 1996), in some cases, sweatshops, leading some to view this phenomenon as a new form of 'imperialism', or neo-colonialism. Given the sheer magnitude of Chinese investments into Africa, it is hardly surprising that this new economic dalliance has come to be seen as a new manifestation of imperialist control. While we found no evidence of sweatshops, the lowcost strategies do little to dispel the myth of 'low-cost imperialism'. Other scholars have identified serious concerns in the employment practices of Chinese firms in Kenya, e.g. Opondo (2009). The key concern our paper identifies is the perception of Kenyan workers, and to some extent managers as reflected in the choice of language used by Chinese managers/investors: 'inefficient', 'inferior', 'do not measure up', 'backward', 'lacking a work ethic', and so forth. This derogatory portrayal - 'otherness' - of Kenyan workers is consistent with the post-colonial depiction of the developing world as inferior to that of the coloniser. At the level of policy, the country appears to acquiesce in this representation of 'backwardness' by failing to challenge the attitudes and contextually inappropriate human resource practices that sustain this narrative, and which include dismissing employees who refuse to work overtime, and marginalising managers, thus preventing knowledge transfer.

Post-colonial theory casts African countries, and African workers, as victims, yet it is too simplistic to define the Africa-China engagement in terms of a dominant power imposing itself on a weaker one, or foreign firms exploiting Africa. The reality becomes more complex if the supposedly 'weaker' party presents itself as a needy recipient of aid and does not pursue appropriate policies to protect its workers from questionable practices. When views consistent with this logic were expressed by Kenyans, they rang a familiar tone. In an example of the inability of the State to give 'voice' to its citizenry, a government official said:

'We have a deliberate shift from West to East which is well-documented. Aid from the West comes with too much baggage ... if you don't become democratic we won't give you this. You almost feel as if you're a prisoner. China does not impose such conditions, but also wants some kind of soft power. African countries realised there's an alternative, so Africa cannot be an equal partner. We need technology and its transfer, trade, but so far it's only one way.' (KN23, Government Official).

When the views came from Chinese, they were particularly poignant. As one investor (CN14, Director, Conglomerate) pointed out, the country squandered opportunities when many prospective investors visit Kenya but do not invest as there are no incentives or preferential 
terms, and are further discouraged by obstacles such as poor infrastructure, corruption, unstable exchange rates and insecurity. Comparing the general socio-economic situation with their own country, Chinese managers/investors saw a more insidious problem in the failure of public policy. The investor above (CN14, Director, Conglomerate) reported:

\section{'The headquarters of UN-HABITAT are located in Nairobi but why are there still housing problems in Nairobi? Don't you think this is a joke? [local investors and policy makers] ... are living in luxurious houses and earning very high incomes'.}

We concur with Childs and Williams (1996) that resistance, overt or otherwise, is central to the post-colonial narrative. While there is much public debate about the challenge to Chinese business practices (some of which was based on misconceptions as noted above), within the organisations in question, there was less evidence of such resistance, except in those cases where employees refused to work overtime or weekends. Given the high levels of unemployment in the country, such refusal posed a serious risk for employees. Managers were even less prone to resistance, and appeared prepared to tolerate their marginalisation and attribute it to 'cultural differences'. In closing, we remain cognisant of the shortcomings of post-colonial theory not merely because of the potential flaw in characterising China's engagement in Africa as 'imperialist', but also because post-colonial theory itself carries a degree of political economy baggage, having been posited as a response to Western colonialism.

\section{Conclusions}

Much prior research has been limited to the experience of Western firms in Africa, and has examined in particular the suitability of their management approaches, cultural differences, and the ways in which they navigate the African institutional investment environment. The influx of investors from the East, particularly, Japan, Malaysia, South Korea and more recently China, has turned the continent into an opportunity for those prepared to negotiate a 'difficult' investment terrain. We considered a sample of Chinese firms' motives for investing in Kenya as well as the circumstances of the individual managers/investors. Our analysis revealed a multi-faceted reality which challenges the common view that the economy has come to be dominated by Chinese SOEs who employ large numbers of Chinese workers. This research has contributed to the literature on management in Africa with specific reference to the AfricaChina phenomenon. It has also contributed to a better understanding of the suitability and 
relevance of post-colonial theory and thus helped to explain the behaviour of Chinese firms and managers in the African context. We hope this will engender further research on how MNCs from other parts of the world view African personnel, and the extent to which they utilise indigenous knowledge and develop talent in Africa.

Further research might consider how the failure to give 'voice' to an African labour force and management cadres differs from the existing approaches by Western firms. This will lead to a better understanding of the types of incompatibilities that prevent the development of appropriate business and human resources practices. In light of the incompatibilities we found for example in mode of communication in the two supposedly 'high-context' societies (Chua et al, 1987), researchers might examine Africa-China relations from the point of view of crosscultural relations, conflict-resolution and social exchange theory. Following Yousfi's (2013) post-colonial account of the imposition of American practices, scholars might examine the extent to which hybridisation is taking place in the Africa-China engagement, and how the introduction of Chinese management practices is impacted by the experience of colonialism and the particular contextual circumstances of Africa. In particular, does the Africa-China engagement open up a new, alternative space for theorising hybridisation and the transfer of management practices? Finally, we suggest that the insights generated here might foster further research on the actual interaction between Chinese and Africans who work in teams, with a view to identifying the nature and determinants of knowledge-sharing.

\section{References}

Adam, I. and Tiffin, H. (1991). Past the last post: Theorising post-colonialism and postmodernism, New York and London: Harvester Wheatsheaf.

Akorsu, A.D. and Cooke, F.L. (2011), 'Labour standards application among Chinese and Indian firms in Ghana: typical or atypical?' The International Journal of Human Resource Management, 22, 13, 2730-2748.

Amankwah-Amoah, J. and Y.A. Debrah (2011), 'Competing for scarce talent in a liberalised environment: evidence from the aviation industry in Africa,' International Journal of Human Resource Management, 22, 3565-3581.

Asiedu, E. (2004), 'The Determinants of Employment of Affiliates of US Multinational Enterprises in Africa,' Development Policy Review, 22, 4, 371-379.

Azolukwam, V.A. and S.J. Perkins (2009), 'Managerial perspectives on HRM in Nigeria: evolving hybridization?' Cross Cultural Management: An International Journal, 16,1, 62-82. 
Bhabha, H.K. (1994), The Location of Culture. New York: Routledge.

Blunt, P. and Jones, M.L. (1997), 'Exploring the limits of Western leadership theory in East Asia and Africa.' Personnel Review, 26: 6-23.

Blunt, P. and Jones, M.L. (1992), Managing Organizations in Africa. Berlin: Walter de Gruyter.

Brautigan, D. and Tang, X. (2011), 'Africa's Shenzhen: China's special economic zones in Africa.' Journal of Modern African Studies, 49: 27-54.

Broadman, H. G. (2007), Africa's silk road: China and India's new economic frontier. Washington, DC: World Bank.

Boisot, M. and Meyer, M.W. (2008), 'Which Way through the Open Door? Reflections on the Internationalization of Chinese firms,' Management and Organization Review, 4, 3, 349365 .

Chang, S., Gong, Y., Way, S.A. and Jia, L. (2013), 'Flexibility-Oriented HRM Systems, Absorptive Capacity, and Market Responsiveness and Firm Innovativeness,' Journal of Management, 39, 7, 1924-1951.

Chen, C.C., Chen, Y. and Xin, K. (2004), 'Guanxi Practices and Trust in Management: A Procedural Justice Perspective,' Organization Science, March/April, 15, 200-209.

Cheng, S. and Liang, G. (2011) 'Social responsibility of Chinese investment in Africa: What does it mean for EU-China cooperation on development policy towards Africa?' International Centre for Trade and Sustainable Development http://ictsd.org/i/china/105753/ (accessed 03/11/2013).

Child, J. and Rodrigues, B. (2004), 'The Internationalization of Chinese Firms: A Case for Theoretical Extension,' Management and Organization Review, 1, 3, 381-410.

Chinese Foreign Ministry, (2006). http://www.china.org.cn/english/features/focac/183441.htm. (Accessed 30/12/2013)

.Childs, P. and Williams, R.J.P. (1996), An Introduction to Post-Colonial Theory. London: Prentice Hall.

Chua, E. G., Gudykunst, W.B. and B. William (1987), 'Conflict resolution styles in low- and high-context cultures,' Communication Research Reports, 4, 1, 32-37.

Darwin, J. (1991), The End of the British Empire: The Historical Debate. Oxford: Blackwell.

Davies, M., Edinger, H. Tay, N. and Naidu, S. (2008), How China Delivers Development Assistance to Africa, Centre for Chinese Studies, University of Stellenbosch. 
DiMaggio, P.J., and Powell, W.W. (1983), 'The iron cage revisited: Institutional isomorphism and collective rationality in organizational fields,' American Sociological Review, 48, $147-160$.

Ding, Y., Zhang, H. and Zhang, J. (2007), 'Private vs State Ownership and Earnings Management: evidence from Chinese listed companies,' Corporate Governance: An International Review, 15, 2, 223-238.

Drogendijk, R. and Blomkvist, K. (2013), 'Drivers and motives for Chinese outward Foreign Direct Investments in Africa,' Journal of African Business 14, 2, 75-84.

Dupasquier, C., and Osakwe, P.N. (2006), 'Foreign Direct Investment in Africa: Performance, Challenges, and Responsibilities,' Journal of Asian Economics, 17, 241-260.

Dyer, W.G.Jr. and Wilkins, A.L. (1991), 'Better Stories, Not Better Constructs, to Generate Better Theory: A Rejoinder to Eisenhardt,'Academy of Management Review, 16: 3, 613619.

Eichengreen, B. and Tong, H. (2006) 'Fear of China,' Journal of Asian Economies, 17: 226240.

Eisenhardt, K.M. (1989), 'Building theories from case study research,' Academy of Management Review, 14, 4, 532-50.

Engardio, P. (2008), Chindia: How China and India are revolutionising global business. New Delhi: Tata McGraw-Hill.

Fijalkowski, L. (2011) 'China’s 'soft power' in Africa.' Journal of Contemporary African Studies, 29:223-232.

Foster, V., Butterfield, W., Chen, C., and Pushak, N. (2008), Building bridges: China's Growing Role as Infrastructure Financier for Sub-Saharan Africa, Washington, DC: The World Bank.

Fung, K. C. and Garcia-Herrero, A. (2012). 'Foreign Direct Investment Outflows from China and India,' China Economic Policy Review, 1, 1, 1-15.

Gabriel, Y. (2000), Storytelling in organizations: Facts, fictions, fantasies. Oxford: Oxford University Press.

Gadzala, A. (2009), 'Survival of the fittest? Kenya's jua kali and Chinese business.' Journal of Eastern African Studies, 3:202-220.

Gamble, J. (2010), 'Transferring Organisational Practices and the Dynamics of Hybridization: Japanese Retail Multinationals in China,' Journal of Management Studies. 47, 705-732.

Gill, B. and Reilly, J. (2007), 'The Tenuous Hold of China Inc. in Africa,' The Washington Quarterly, 30, 3: 37-52. 
Gill, B., Huang, C. and Morrison, J. (2007), 'Assessing China's Growing Influence in Africa,' China Security, 3: 3-21.

Gillham, B. (2000), The Research Interview. London: Continuum.

Gomez, E., Angwin, D., Peter, E., and Mellahi, K. (2012) 'HRM issues and outcomes in African mergers and acquisitions: a study of the Nigerian banking sector.' International Journal of Human Resource Management, 14: 2874-2900.

Graham, J.L. and Lam, N.M. (2003), 'The Chinese Negotiation,' Harvard Business Review, October, 1-12.

Gu, J. (2009), 'China's private enterprises in Africa and the implications for African development'. European Journal of Development Research, 21: 570-587.

Gudykunst W.B., Ting-Toomey, S. and Nishida, T. (1996), Communication in Personal Relationships Across Cultures. Thousand Oaks, CA.: Sage.

Hagland, D. (2009), 'In it for the long term? Governance and learning among Chinese Investors in Zambia's copper sector.' The China Quarterly, 199: 627-646.

Hanusch, M. (2012), 'African perspectives on China-Africa: Modelling popular perceptions and their economic and political determinants'. Oxford Development Studies, 40: 492516.

Hart, S.L. and Christensen, C.M. (2002), 'The great leap: Driving innovation from the base of the pyramid.' MIT Sloan Management Review, fall, 23-33.

He, W.P. (2009), 'China’s African policy'. African Review, 1:35-53.

Henley, J.S. (1977), 'The personnel professionals in Kenya.' Personnel Management, 9(2):10-14.

Horwitz, F. M. (2012), Evolving human resource management in Southern African multinational firms: towards an Afro-Asian nexus. International Journal of Human Resource Management 23:

Horwitz, F. M., Kamoche, K. and Chew, I.K.H (2002), 'Looking East: diffusing high performance work practices in the southern Afro-Asian context,' International Journal of Human Resource Management, 13, 7, 1019-1041.

Hurst, W. (2009), The Chinese Worker after Socialism, Cambridge and New York: Cambridge University Press.

Idiagbon-Oke, M. and Oke, A. (2011), 'Implementing innovative flexible work practices in Nigerian local firms: Implications for management of change in less-developed countries,' Journal of Occupational and Organizational Psychology, 84, 518-543.

Jackson, T. (2012), 'Postcolonialism and organizational knowledge in the wake of China's presence in Africa: interrogating South-South relations,' Organization, 19, 2, 181-204. 
Jackson, T., Amaeshi, K. and Yavuz, S. (2008), 'Untangling African indigenous management: Multiple influences on the success of SMEs in Kenya,' Journal of World Business, 43, 400-416.

Jackson, T. (2004), Management and change in Africa: A cross-cultural perspective. London: Routledge.

Jackson, T., Louw, L. and Zhao, S. (2013), 'China in sub-Saharan Africa: implications for HRM policy and practice at organizational level,' The International Journal of Human Resource Management, 24, 13, 2512-2533.

Jenkins, R. and Edwards, C. (2006), 'The economic impacts of China and India on sub-Saharan Africa: Trends and prospects.' Journal of Asian Economies, 17:207-225.

Johnson, J.P., Lenartowicz, T. and Apud, S. (2006), 'Cross-cultural competence in international business: toward a definition and a mode,' Journal of International Business Studies, 37, 525-543.

Judith, M.Z. (2012), 'Employee empowerment and organizational commitment: A study of the food manufacturing sector in Zimbabwe,' African Journal of Business Management, 6, $38,10332-10339$.

Kamoche, K. (2011), 'Contemporary developments in the management of human resources in Africa,' Journal of World Business, 46, 1, 1-4.

Kamoche, K. (2000), Sociological Paradigms and Human Resources: An African Context. Aldershot: Ashgate.

Kamoche, K, Chizema, A., Mellahi, K. and Newenham-Kahindi. A. (2012), 'New directions in the management of human resources in Africa,' International Journal of Human Resource Management, 23, 2823-2834.

Kamoche, K., and Harvey, M. (2006) 'Knowledge diffusion in the African context: an institutional theory perspective'. Thunderbird International Business Review, 48: 157-181.

Kamoche, K., Debrah, Y., Horwitz, F., and Muuka G.N. (eds) (2004a). Managing Human Resources in Africa. London: Routledge.

Kamoche, K. and Newenham-Kahindi, A. (2012), 'HRM and knowledge appropriation: the MNC experience in Tanzania,' International Journal of Human Resource Management, $23,2854-2873$.

Kamoche, K., Nyambegera, S.M. and Mulinge, M.M. (2004b), 'HRM in Kenya', in Kamoche, K., Debrah, Y., Horwitz, F., and Muuka G.N. (eds) (2004). Managing Human Resources in Africa. London: Routledge. 
Kopinski, D., Polus, A. and Taylor, I. (2011) 'Contextualizing Chinese engagement in Africa.' Journal of Contemporary African Studies, 29: 129-136.

Kragelund, P. (2009), 'Knocking on a wide-open door: Chinese investments in Africa,' Review of African Political Economy, 122, 479-497.

Kurlantzick, J. (2006), 'Beijing’s Safari: China’s Move into Africa and Its Implications for Aid, Development, and Governance,' China Program, Carnegie Endowment for International Peace, Washington DC, November.

Langdon, S. (1981), The Multinational Corporation in the Kenyan Political Economy. London: Macmillan.

Li, J., Newenham-Kahindi, A., Shapiro, D.M., and V.Z. Chen (2013), 'Theory and evidence from China's natural resource investments in Africa'. Global Strategy Journal, 3:300321.

Lin, J.Y. and Wang, Y. (2012), 'China's integration with the world: Development as a process of learning and industrial upgrading,' China Economic Policy Review, 1, 1, 1-33.

Lituchy, T.R., D. Ford, \& B.J. Punnett, (2013) 'Leadership in Uganda, Barbados, Canada and the USA: exploratory perspectives', African Journal of Economic and Management Studies, 4:201-222.

McMahon, D. (2011), 'Bank: China Africa investment to jump 70\% by 2015'. Wall Street Journal, 22 February. Accessed: http://blogs.wsj.com/chinarealtime/2011/02/22/bankchina-africa-investment-to-jump-70-by-2015/

Mangaliso, M.P. (2001,) 'Building competitive advantage from Ubuntu: Management lessons from South Africa.' Academy of Management Executive, 15:23-33.

Maruyama, M. (1984), 'Alternative concepts of management: Insights from Asia and Africa. Asia Pacific Journal of Management, 1, 2, 100-111.

Newenham-Kahindi, A., Kamoche, K., Chizema, A., and Mellahi, K. (2013), Effective People Management. Palgrave MacMillan.

Nkomo, S (2011), 'A postcolonial and anti-colonial reading of 'African' leadership and management in organization studies: tensions, contradictions and possibilities'. Organization, 18: 365-386.

Okpara, J.O. and Kabongo, J.D. (2011), 'Cross-cultural training and expatriate adjustment: A study of western expatriates in Nigeria'. Journal of World Business, 46: 22-30.

Onyemelukwe, C.C. (1973), Men and Management in Contemporary Africa. London: Longman. 
Opondo, M. (2009), 'The Impact of Chinese Firms on CSR in Kenya's Garment Sector,' The International Research Network on Business, Development and Society. BDS Working Paper No.7, 1-18.

Peng, M.W. and Luo, Y. (2000), 'Managerial ties and firm performance in a transition economy: the nature of a micro-macro link,' Academy of Management Journal, 43, 3, 486-501.

Pinnington, A.; Kamoche, K. and Suseno, Y. (2009), 'Property in Knowledge Work: An Appropriation-Learning Perspective,' Employee Relations, 31, 57-80.

Prasad, A. (ed) (2003), Postcolonial Theory and Organizational Analysis: A Critical Engagement. New York: Palgrave Macmillan.

Ragin, C.C. (1994), Constructing social research: The unity and diversity of method, Thousand Oaks, CA: Pine Forge Press.

Richards, T.J. and Richards, L. (1994), 'Using computers in qualitative research,' in N.K. Denzin and Y.S. Lincoln (Eds.), Handbook of qualitative research, pp. 445-462, London: Sage.

Said, E. (1978/1995). Orientalism. London: Penguin.

Shaw, T.M., Cooper, A.F. and Antkiewicz, A. (2007), 'Global and/or Regional Development at the Start of the $21^{\text {st }}$ Century? China, India and (South) Africa,' Third World Quarterly, $28,7,1255-70$.

Siebers. L.Q. (2011), Retail Internationalisation in China: Expansion of Foreign Retailers, Basingstoke: Palgrave Macmillan.

Siebers, L.Q. (2012), 'Foreign Retailers in China: the First Ten Years,' Journal of Business Strategy. 33, $27-38$.

Snow, P. (1988), The Star Raft: China's Encounter with Africa. Weidenfeld and Nicolson.

Southall, R. and Melber H. (2009). A new scramble for Africa? Imperialism, investment and development. Pietermaritzburg: University of Kwazulu-Natal Press.

Spivak, G. (1990), 'Poststructuralism, marginality, postcoloniality and value,' in P. Mongia (Ed.), Contemporary Postcolonial Theory. London: Arnold, 198-221.

State Council Information Office of People's Republic of China (2013), 'Kenya expects to enhance high-tech enterprises collaborations with China', www.scio.gov.cn, $22^{\text {nd }}$ September.

http://www.scio.gov.cn/ztk/wh/2013/gzzgnrlyknyx/929217/Document/1346533/134653 3.htm (accessed date: 25/12/2013).

Strauss, A. (1987), Qualitative Analysis for Social Scientists, New York: Cambridge University Press. 
Taylor, I. (2006), 'China’s oil diplomacy in Africa.' International Affairs, 82: 937-969.

Taylor, I. (1998), 'China's foreign policy towards Africa in the 1990s' Journal of Modern African Studies, 36: 443-460.

Thiam, I.D. and Mulira, J. (1999), 'Africa and the Socialulist Countries,' in Ali, A, Mazrui (ed.), General History of Africa, Vol. VIII Africa Since 1935, Chapter 27, CA: University of California Press.

Thite, M., Wilkinson, A. and Shah, D. (2012), 'Internationalization \& HRM Strategies across Subsidiaries in Multinational Corporations from Emerging Economies - A Conceptual Framework,' Working paper. Australia: Griffith Business School, Griffith University.

Ukaegbu, C.C. (2000), 'Working conditions and employee commitment in indigenous private manufacturing firms in Nigeria: Managing business organizations for industrial development,' Journal of Modern African Studies, 38, 295-324.

Wallerstein, I. (1983), Historical Capitalism, London: Verso.

Walumbwa, F.O., Avolio, B.J. and Aryee, S. (2011), 'Leadership and management research in Africa: A synthesis and suggestions for future research,' Journal of Occupational and Organizational Psychology, 84, 425-439.

Wang, J., Wang, G.G., Ruona, E.A.W. and Rojewski, W.J. (2005), 'Confucian Values and the Implications for IHRD,' Human Resource Development International, 8, 311-326.

Whyte, W.F. (1994), 'Interviewing in Field Research,' In R.G. Burgess (ed.), Field Research: a Sourcebook and Field Manual, London and New York: Routledge.

Wood, G., Dibben, P., Stride, C. and Webster, E. (2011). 'HRM in Mozambique: Homogenization, path dependence or segmented business system? Journal of World Business, 46 (1) 31-41

Young, R.J.C. (2001), Postcolonialism: An Historical Introduction. Malden, MA: Blackwell.

Yousfi, H. (2013), 'Rethinking hybridity in postcolonial contexts: What changes and what persists? The Tunisian case of Poulina's managers'. Organization Studies, doi: $10.1177 / 0170840613499751$

Yin, R. (1994), Case study research: Design and methods, 2nd ed, Thousand Oaks: Sage. 
Table 1 Summary of interview details $(2011-2014)$

\begin{tabular}{|l|l|l|}
\hline Categories & Summary statistics \\
\hline Interviewee numbers and nationality & \multicolumn{2}{l|}{} \\
\hline Chinese & 31 & $50 \%$ \\
\hline Kenyan & 30 & $48 \%$ \\
\hline Nigerian & 1 & $2 \%$ \\
\hline Total & 62 & $100 \%$ \\
\hline Language used with interviewees & \multicolumn{2}{l|}{} \\
\hline Chinese only & 11 & $18 \%$ \\
\hline English only & 47 & $76 \%$ \\
\hline Chinese and English & 4 & $6 \%$ \\
\hline Total & 62 & $100 \%$ \\
\hline Gender & \multicolumn{2}{|l|}{} \\
\hline Female & 12 & $19 \%$ \\
\hline Male & 50 & $81 \%$ \\
\hline Total & 62 & $100 \%$ \\
\hline Sectors the firms were drawn from & \\
\hline Construction/engineering & 8 & $28 \%$ \\
\hline Manufacturing & 5 & $18 \%$ \\
\hline Catering & 3 & $10 \%$ \\
\hline Service & 3 & $10 \%$ \\
\hline Trading & 2 & $7 \%$ \\
\hline Conglomerate & 2 & $7 \%$ \\
\hline Media & 2 & $7 \%$ \\
\hline Non-profit & 2 & $7 \%$ \\
\hline Mining & 1 & $3 \%$ \\
\hline Retail & 1 & $100 \%$ \\
\hline Total & 29 & \\
\hline & \multicolumn{2}{l}{} \\
\hline
\end{tabular}

